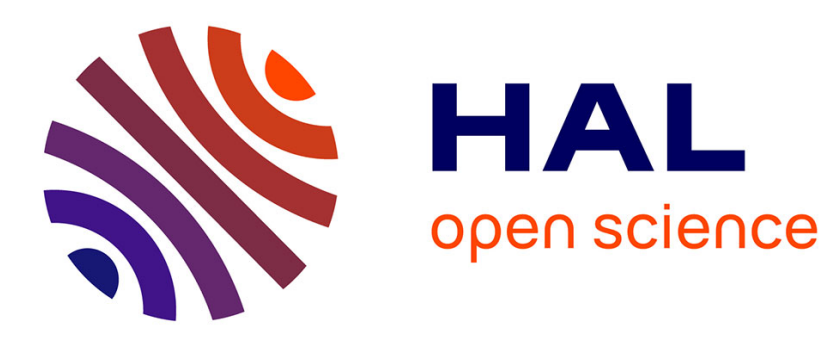

\title{
Impairment of methionine sulfoxide reductase during UV irradiation and photoaging
}

Cédric R. Picot, Marielle Moreau, Mylène Juan, Emmanuelle Noblesse, Carine Nizard, Isabelle Petropoulos, Bertrand Friguet

\section{To cite this version:}

Cédric R. Picot, Marielle Moreau, Mylène Juan, Emmanuelle Noblesse, Carine Nizard, et al.. Impairment of methionine sulfoxide reductase during UV irradiation and photoaging. Experimental Gerontology, 2007, 42 (9), pp.859. 10.1016/j.exger.2007.02.006 . hal-00499010

\section{HAL Id: hal-00499010 https://hal.science/hal-00499010}

Submitted on 9 Jul 2010

HAL is a multi-disciplinary open access archive for the deposit and dissemination of scientific research documents, whether they are published or not. The documents may come from teaching and research institutions in France or abroad, or from public or private research centers.
L'archive ouverte pluridisciplinaire HAL, est destinée au dépôt et à la diffusion de documents scientifiques de niveau recherche, publiés ou non, émanant des établissements d'enseignement et de recherche français ou étrangers, des laboratoires publics ou privés. 


\section{Accepted Manuscript}

Impairment of methionine sulfoxide reductase during UV irradiation and photoaging

Cédric R. Picot, Marielle Moreau, Mylène Juan, Emmanuelle Noblesse, Carine Nizard, Isabelle Petropoulos, Bertrand Friguet

PII: $\quad$ S0531-5565(07)00036-8

DOI: $\quad$ 10.1016/j.exger.2007.02.006

Reference: $\quad$ EXG 8314

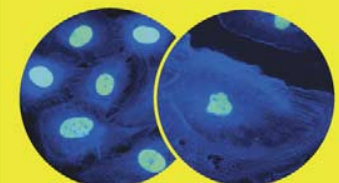

To appear in:

Experimental Gerontology

Received Date: $\quad 22$ December 2006

Revised Date: $\quad 31$ January 2007

Accepted Date: $\quad 8$ February 2007

Please cite this article as: Picot, C.R., Moreau, M., Juan, M., Noblesse, E., Nizard, C., Petropoulos, I., Friguet, B., Impairment of methionine sulfoxide reductase during UV irradiation and photoaging, Experimental Gerontology (2007), doi: 10.1016/j.exger.2007.02.006

This is a PDF file of an unedited manuscript that has been accepted for publication. As a service to our customers we are providing this early version of the manuscript. The manuscript will undergo copyediting, typesetting, and review of the resulting proof before it is published in its final form. Please note that during the production process errors may be discovered which could affect the content, and all legal disclaimers that apply to the journal pertain. 


\section{Impairment of methionine sulfoxide reductase during UV irradiation and photoaging}

Cédric R. Picot ${ }^{1,2}$, Marielle Moreau ${ }^{2}$, Mylène Juan², Emmanuelle Noblesse ${ }^{2}$, Carine Nizard ${ }^{2}$, Isabelle Petropoulos ${ }^{1}$, Bertrand Friguet ${ }^{1} *$

${ }^{1}$ Laboratoire de Biologie et Biochimie Cellulaire du Vieillissement, EA 3106 / IFR 117, Université Paris 7-Denis Diderot, 2 place Jussieu, Tour 33-23, $1^{\text {er }}$ étage, CC 7128, 75251 Paris cedex 05, France.

${ }^{2}$ LVMH-Recherches, Laboratoires R \& D, Branche Parfums-Cosmétiques, 45804 Saint-Jeande-Braye cedex, France.

*Corresponding author: Phone / Fax : 33-1-44 278234

Laboratoire de Biologie et Biochimie Cellulaire du Vieillissement, EA 3106 / IFR 117, Université Paris 7-Denis Diderot, 2 place Jussieu, Tour 33-23, $1^{\text {er }}$ étage, CC 7128, 75251 Paris cedex 05

e-mail : bfriguet@paris7.jussieu.fr

Running title: Methionine sulfoxide reductase and photoaging

Keywords: Methionine sulfoxide reductase; MsrA; UV irradiation; photoaging; oxidized protein repair. 


\title{
ACCEPTED MANUSCRIPT
}

\begin{abstract}
During chronic UV irradiation, which is part of the skin aging process, proteins are damaged by reactive oxygen species resulting in the accumulation of oxidatively modified protein. UV irradiation generates irreversible oxidation of the side chains of certain amino acids resulting in the formation of carbonyl groups on proteins. Nevertheless, certain amino acid oxidation products such as methionine sulfoxide can be reversed back to their reduced form within proteins by specific repair enzymes, the methionine sulfoxide reductases $\mathrm{A}$ and B. Using quantitative confocal microscopy, the amount of methionine sulfoxide reductase A was found significantly lower in sun-exposed skin as compared to sun-protected skin. Due to the importance of the methionine sulfoxide reductase system in the maintenance of protein structure and function during aging and conditions of oxidative stress, the fate of this system was investigated after UVA irradiation of human normal keratinocytes. When keratinocytes are exposed to $15 \mathrm{~J} / \mathrm{cm}^{2}$ UVA, methionine sulfoxide reductase activity and content is decreased, indicating that the methionine sulfoxide reductase system is a sensitive target for UV-induced inactivation.
\end{abstract}

\footnotetext{
Abbreviations

Msr : Methionine Sulfoxide Reductase; ROS : Reactive Oxygen Species.
} 


\section{Introduction}

The harmful effect of UV irradiation of skin is related to the production of reactive oxygen species that are altering cellular components including proteins (Berneburg et al., 2000; Wlaschek et al., 2001). In mammalian cells, oxidized proteins are readily degraded by the proteasome in both the nucleus and the cytosol (Grune et al., 1997) while the Lon protease has been shown to degrade oxidized protein in the mitochondria (Bota and Davies 2002). Accumulation of oxidized proteins and impairment of proteasome function was observed in aging epidermis (Bulteau et al., 2000; Petropoulos et al., 2000). We have previously reported that UV irradiation of human keratinocytes results in a concomitant accumulation of oxidatively modified proteins and decrease of proteasome peptidase activities. This decrease of proteasome activity in UV irradiated cells was attributed to the generation of endogeneous inhibitors such as proteins modified and cross-linked by the lipid peroxidation product 4hydroxy-2-nonenal (Bulteau et al., 2002). Nevertheless, degradation represents the final step in the elimination of oxidatively modified protein. Certain forms of oxidative modification, notably to sulfur-containing amino acids, can be reversed by specific enzymatic systems representing protein repair and/or redox regulation of protein function (Mary et al., 2004; Petropoulos and Friguet 2005; Petropoulos and Friguet 2006). Oxidation of methionine in protein produces methionine-S-sulfoxide and methionine-R-sulfoxide that can be catalytically reduced by two stereospecific enzymes, methionine sulfoxide reductases A (MsrA) and B (MsrB), respectively (Grimaud et al., 2001; Hansel et al., 2005; Moskovitz et al., 1996a). We have previously reported that MsrA and MsrB2, the mitochondrial member of the MsrB family, are downregulated during replicative senescence of WI-38 human fibroblasts (Picot et al., 2004). In young cells, Msr activity is increased in response to low doses of $\mathrm{H}_{2} \mathrm{O}_{2}$ while higher doses resulted in decreased Msr activity. In addition, overexpression of MsrA was found to protect immortalized WI-38 SV40 human fibroblasts against $\mathrm{H}_{2} \mathrm{O}_{2}-$ mediated 
oxidative stress by reducing the amount of intracellular reactive oxygen species (ROS) and the extent of irreversible protein oxidative damage. In contrast, no protective effect was observed when the cells were exposed to UVA irradiation (Picot et al., 2005). Relatively little information exists as to the fate of the Msr system during UV irradiation. Indeed, repetitive exposure of human skin to solar-stimulated light resulted in an enhanced expression of MsrA in the epidermis and MsrA was found upregulated in HaCat cells in response to low doses of UVA while UVB lowered MsrA protein expression (Ogawa et al., 2006). In this paper, we have addressed the fate of MsrA upon exposure of cultured human normal keratinocytes to high dose of UVA and during photoaging by comparing MsrA expression levels in sunprotected and sun-exposed skin.

\section{Methionine sulfoxide reductase}

Methionine residues in proteins can be oxidized to $\mathrm{S}$ and $\mathrm{R}$ sulfoxide diastereoisomeric forms resulting in loss in protein function. The methionine sulfoxide reductase enzymes, MsrA and MsrB, can regenerate methionine and in certain proteins, enzymatic reduction of methionine sulfoxide results in the recovery of protein function (Moskovitz 2005; Vougier et al., 2004). In eukaryotes, MsrA is expressed from a single gene and is found in the cytosol and mitochondria in nearly all cell types (Hansel et al., 2005; Vougier et al., 2003) and in the nucleus of mouse cells (Kim and Gladyshev 2005) and human melanocytes (Schallreuter et al., 2006). MsrB are zinc-containing enzymes that are encoded by 3 different genes designated as: 1) MsrB1 (SelX), a selenoprotein present in the nucleus and the cytosol; 2) MsrB2 (CBS-1), localized in the mitochondria; and 3) MsrB3A/B (generated by alternative splicing), targeted to the endoplasmic reticulum and to the mitochondria, respectively (Hansel et al., 2005). 
$\underline{\text { Gene and protein expression of MsrA and B have been monitored in different organs }}$ and tissues in rat and human. MsrA mRNA was found highly expressed in rat and human kidney (Moskovitz et al., 1996a). The MsrA protein was found in all rat tissues examined but was specifically localized in renal medulla, retinal pigmented epithelial cells, blood and alveolar macrophages, neurons and throughout the nervous system (Moskovitz et al., 1996b). In human, gene expression of MsrA, MsrB2 and MsrB3 was found in all tissues examined with the highest expression of msrA RNA observed in kidney, cerebellum and liver. MsrB2 mRNA was found highly expressed in heart, skeletal muscle and liver while msrB3 highest expression was observed in bladder, aorta, heart and skeletal muscle (Hansel et al., 2005). However, the status of the methionine sulfoxide reductases in human skin has been adressed only very recently. In fact, MsrA is present in human skin and exhibits a strong expression in keratinocytes and melanocytes and a lower expression in dermal fibroblasts (Ogawa et al., 2006) while all three msrB mRNA are expressed in melanocytes (Schallreuter et al., 2006).

Msr enzymes, particularly MsrA, play critical roles in protein repair and contribute to cellular redox homeostasis (Levine et al., 1996). During aging or after an oxidative stress, the reported decrease in Msr activity has been proposed to contribute to the observed accumulation of oxidatively damaged protein (Petropoulos et al., 2001; Picot et al., 2004). MsrA null mutant mice exhibit a shortened lifespan and present higher levels of protein carbonyls when exposed to hyperoxia, which indicates an increased sensitivity towards oxidative stress (Moskovitz et al., 2001). The silencing of MsrA and all the MsrB enzymes in human lens cells leads to the increased oxidative stress-induced cell death (Marchetti et al., 2006; Marchetti et al., 2005). Conversely, the overexpression of MsrA in yeast, in neuronal PC 12 cells or in WI-38 SV40 human fibroblasts confers resistance toward different forms of oxidative stress (Moskovitz et al., 1998; Yermolaieva et al., 2004) by reducing the 
intracellular ROS content and limiting the accumulation of oxidative damage to proteins (Picot et al., 2005).

\section{Decreased expression of MsrA in sun-exposed epidermis compared to sun-protected}

Since MsrA is expressed at a high level in human epidermis and the Msr system has been shown to play an important role in ROS detoxification, MsrA expression status has been investigated in both sun-exposed and sun-protected skin from human donors. Serial crosssections of skin biopsies taken from the upper (sun-exposed) and inner (sun-protected) of the forearm from 16 female donors, were analyzed by immunohistochemistry with a polyclonal anti-MsrA antibody as described in the legend to Fig. 1. A strong epidermal and low dermal expression of MsrA was observed in both situation and most of the MsrA immunostaining was present in the cytosol of keratinocytes while the nucleus was almost not immunoreactive for MsrA (Fig. 1A and 1B). Interestingly, a small (about 20\%) but significant decrease of MsrA expression was found in sun-exposed skin as compared to sun-protected skin (Fig. 1C). This downregulation of MsrA at the protein level was further confirmed in complementary experiments where mRNA expression levels of both MsrA and MsrB2 in epidermal cells were found to be decreased by almost two-fold in sun-exposed compared to sun-protected skin as assessed by light cycler quantitative RT-PCR (data not shown). Taken together, these results indicate that chronic sun-exposure, also referred as photoaging, would result in a decreased expression of two main components of the methionine sulfoxide reductase system, MsrA and MsrB2.

\section{UVA induced decrease of methionine sulfoxide reductase activity}

To investigate the effect of UVA irradiation on Msr activity and MsrA protein expression, cultured human normal keratinocytes were exposed to a sublethal dose of $15 \mathrm{~J} / \mathrm{cm}^{2}$ 
UVA. As reported in Fig. 2C, an increase of oxidized proteins was observed 24 hours after UVA irradiation by monitoring the protein carbonyl content after derivatization of total soluble proteins by dinitrophenylhydrazine, separation of the protein on a SDS-PAGE and immunodetection with an anti-DNP antibody (Oxyblot assay, AbCys S.A., Paris, France). In addition, a concomitant and significant $30 \%$ loss of total Msr activity was observed in UVA irradiated cells as compared to control cells, indicating that the Msr system is affected by UVA irradiation (Fig. 2A). To begin to assess whether the inhibition of the Msr activity observed was resulting, at least in part, to a reduced expression of MsrA following UVA stress, the MsrA expression level was assessed by western blotting of soluble protein extracts with an anti-MsrA antibody (Fig. 2B). Interestingly, 24 hours after UVA irradiation, the MsrA protein was found downregulated in irradiated cells as compared to control cells indicating that exposure to relatively high doses of UVA results in a downregulation of MsrA which parallels the decline in total intracellular Msr activity.

\section{Summary and Future Directions}

In summary, both chronic sun exposure of human epidermis and high dose UVA irradiation of cultured human keratinocytes result in a decline of MsrA expression and/or Msr activity. Although most of the studies have evidenced UV exposure alterations of dermal components and fibroblasts function (Berneburg et al., 2000; Scharffetter-Kochanek et al., 2000), recent data indicates that keratinocytes could also be involved in the photoaging process. Indeed, a decreased expression of $\beta 1$ integrin has been recently reported in sunexposed skin pointing out an impairment of epidermal homeostasis upon chronic UV exposure (Bosset et al., 2003). We have previously reported that UV irradiation of human normal keratinocytes results in an accumulation of oxidatively modified proteins (Bulteau et al., 2002). This oxidized protein build-up has been attributed to a UV-induced decline in 
proteasomal function that became inhibited by highly modified proteins and less efficient for the degradation of oxidized proteins (Bulteau et al., 2002). Due to the importance of the Msr system in the maintenance of protein structure and function during aging and in conditions of oxidative stress, the fate of MsrA was investigated in sun-exposed skin in vivo and after UVA irradiation of human normal keratinocytes in vitro. In both situations, the observed impairment of the Msr system may therefore contribute to a higher sensitivity of keratinocytes if challenged by an oxidative stress, especially to the accumulation of oxidatively modified proteins. Interestingly, low doses of UVA irradiation of human epidermis and cultured HaCat cells has been reported to stimulate MsrA expression while UVB treatment of cultured HaCat cells was found to downregulate MsrA expression (Ogawa et al., 2006). Moreover, we have also previously reported that Msr activity is increased in WI-38 human fibroblasts in response to low doses of $\mathrm{H}_{2} \mathrm{O}_{2}$ while higher doses resulted in decreased Msr activity (Picot et al., 2005). Therefore, depending on the intensity of the oxidative stress or UV exposure, Msr enzymes can be either stimulated or impaired which corresponds to a behaviour most often referred as to a hormetic response to environmental stresses (Rattan 2004). Importantly, a loss in Msr activity would be expected to diminish the antioxidant response and unfavourably influence recovery of keratinocytes from oxidative stress encountered during UV irradiation. Taken together, our findings underscore the importance of investigating the effects of UV exposure and other oxidative stress situations on enzymes responsible for repair of specific forms of oxidative modification. Such studies will help to elucidate the contribution of these enzymes to intrinsic skin aging and photoaging. 


\section{Figure legends}

\section{Figure 1. Effect of chronic sun-exposure of human skin on epidermal MsrA expression.}

Forearm skin was obtained from 16 female donors (aged 53-64 years). The study was in agreement with the principles of the Helsinki Declaration. Skin punch biopsies were obtained from the inner side of the forearm (A: sun-protected) and from the upper side of the forearm (B: sun-exposed). Biopsies were snap frozen in liquid nitrogen and stored at $-80^{\circ} \mathrm{C}$ before being cut in serial cross-sections of $10 \mu \mathrm{m}$ thickness and mounted on to silanized slides (Dako, Trappes, France). Sections were fixed in acetone at $-20^{\circ} \mathrm{C}$ for $10 \mathrm{~min}$ and were washed for $2 \mathrm{~min}$ in PBS two times. Slides were incubated at room temperature in a dark humid chamber with a polyclonal anti-MsrA antibody (1/10 000), then they were washed in PBS twice and the secondary antibody (labelled with Alexa 546, 1/500) was applied for $1 \mathrm{~h}$ at room temperature. The slides were washed in PBS and mounted with glycergel (Dako, Trappes, France). Sections were analysed with a Bio-Rad confocal microscope (MRC 1024 ES; Microscience Division, Hemel Hempstead, U.K) with a 400X magnification. Images were obtained by sequential optical sectioning (Kalman series, $n=1$ ). (C) For quantification, sections were analysed by the staining intensity (pixel numbers) using Mocha (Jandel Scientific,Chicago, IL, U.S.A.) and Visilog 5 (Noesi Vision Inc., Saint-Laurent, QC, Canada) softwares. Immunostaining data were analysed with a repeated measures analysis of variance for comparison between sun-exposed skin and sun-protected skin control. Differences were considered significant when $\mathrm{p}<0.05$. 
Figure 2. Effect of UVA irradiation of human normal keratinocytes on Msr activity and MsrA protein level

Keratinocytes were prepared from plastic surgery (mammary gland reductions). Skin fragments were rinsed one time in ethanol $70 \%$ and then in PBS, pH 7.4. Skin was cut into thin strips of $1 \mathrm{~cm}$. Epidermis was separated of dermis by incubation of these fragments during $4 \mathrm{~h}$ at $37^{\circ} \mathrm{C}$ in $0.25 \%(\mathrm{w} / \mathrm{v})$ trypsin, $1 \%$ penicillin - streptomycin. After filtration, centrifugation, keratinocytes were resuspended, counted, and plated in Dulbecco Minimal Essential Medium containing $10 \%(\mathrm{v} / \mathrm{v})$ fetal calf serum, $1 \%$ penicillin - streptomycin, at $37^{\circ} \mathrm{C}$ and $5 \% \mathrm{CO}_{2} .24 \mathrm{~h}$ later, medium was changed for $\mathrm{K}-\mathrm{SFM}$ with $10 \mathrm{ng} / \mathrm{mL}$ of mouse epidermal growth factor, $1 \mathrm{nM}$ of choleric toxin. Cells were grown to $80 \%$ confluence on a 35 mm plastic culture dishes (Corning Costar, Cambridge, MA, USA). To avoid toxicity induced by UV exposure of the culture medium compounds, irradiation was achieved in PBS, pH 7.4. Cells were exposed to a sublethal dose of UVA $\left(15 \mathrm{~J} / \mathrm{cm}^{2}\right)$ with an emission centred at $365 \mathrm{~nm}$ using a Bio-Sun RMX 3W (Vilber-Lourmat, France) as UV source. After irradiation, the PBS was removed and the keratinocytes were incubated in medium at $37^{\circ} \mathrm{C}$ and $5 \% \mathrm{CO}_{2}$ for $24 \mathrm{~h}$. Control cells were treated in the same way but were not irradiated. Cellular homogenates were obtained after disruption of cells by sonication in a buffer containing Tris $\mathrm{HCl} 5 \mathrm{mM} \mathrm{pH} \mathrm{7.5,}$ saccharose $0,25 \mathrm{M}, \mathrm{MgSO}_{4}$ 0,2 mM, EDTA $20 \mathrm{mM}$ and $0.2 \%$ Triton X-100 at $4^{\circ} \mathrm{C}$. Cell debris and organelles were removed from the crude extracts by centrifugation for $30 \mathrm{~min}$ at 20 $000 \mathrm{~g}$ at $4^{\circ} \mathrm{C}$. Protein concentrations were determined by the Bradford method using the protein microassay (Bio-Rad, Marne la Coquette, France).

(A) Msr activity was determined in total protein extract using $N$-acetyl $\left[{ }^{3} \mathrm{H}\right] \operatorname{Met}-R, S(\mathrm{O})$ as substrate (Picot et al., 2004). The reaction was done for 30 min with $30 \mu \mathrm{g}$ of total protein extracts and the activity in non-irradiated cells was taken as $100 \%$. Error bars represent the 


\section{ACCEPTED MANUSCRIPT}

SEM of three independent experiments. Statistical comparisons were performed utilizing the Student's t-test. Differences were considered statistically significant at $\mathrm{p}<0.05(*)$.

(B) Oxidized proteins were detected after SDS-PAGE followed by an electrotransfer onto a nitrocellulose membrane. Before electrophoresis, cellular extracts $(4 \mu \mathrm{g}$ protein) were treated with a solution of dinitrophenylhydrazine to derivatize protein carbonyls to dinitrophenylhydrazone (Oxyblot assay, AbCys S.A., Paris, France). Detection of oxidized proteins was achieved using a polyclonal antibody anti-DNP and the West-Pico chemiluminescence assay (Perbio Sciences, Brebières, France).

(C) Expression of MsrA was detected by western blot. Briefly, $30 \mu \mathrm{g}$ of total protein extract were separated by $12 \%$ SDS-PAGE and transferred into a nitrocellulose membrane. MsrA was detected using a polyclonal antibody (1/40 000). 


\section{References}

Berneburg, M., Plettenberg, H., Krutmann, J., 2000. Photoaging of human skin. Photodermatol Photoimmunol Photomed. 16, 239-44.

Bosset, S., Bonnet-Duquennoy, M., Barre, P., Chalon, A., Lazou, K., Kurfurst, R., Bonte, F., Schnebert, S., Disant, F., Le Varlet, B., Nicolas, J. F., 2003. Decreased expression of keratinocyte beta1 integrins in chronically sun-exposed skin in vivo. Br J Dermatol. $148,770-8$.

Bota, D. A., Davies, K. J., 2002. Lon protease preferentially degrades oxidized mitochondrial aconitase by an ATP-stimulated mechanism. Nat Cell Biol. 4, 674-80.

Bulteau, A. L., Moreau, M., Nizard, C., Friguet, B., 2002. Impairment of proteasome function upon UVA- and UVB-irradiation of human keratinocytes. Free Radic Biol Med. 32, 1157-70.

Bulteau, A. L., Petropoulos, I., Friguet, B., 2000. Age-related alterations of proteasome structure and function in aging epidermis. Exp Gerontol. 35, 767-77.

Grimaud, R., Ezraty, B., Mitchell, J. K., Lafitte, D., Briand, C., Derrick, P. J., Barras, F., 2001. Repair of oxidized proteins. Identification of a new methionine sulfoxide reductase. J Biol Chem. 276, 48915-20.

Grune, T., Reinheckel, T., Davies, K. J., 1997. Degradation of oxidized proteins in mammalian cells. Faseb J. 11, 526-34.

Hansel, A., Heinemann, S. H., Hoshi, T., 2005. Heterogeneity and function of mammalian MSRs: enzymes for repair, protection and regulation. Biochim Biophys Acta. 1703, 239-47.

Kim, H. Y., Gladyshev, V. N., 2005. Role of structural and functional elements of mouse methionine-S-sulfoxide reductase in its subcellular distribution. Biochemistry. 44, 8059-67.

Levine, R. L., Mosoni, L., Berlett, B. S., Stadtman, E. R., 1996. Methionine residues as endogenous antioxidants in proteins. Proc Natl Acad Sci U S A. 93, 15036-40.

Marchetti, M. A., Lee, W., Cowell, T. L., Wells, T. M., Weissbach, H., Kantorow, M., 2006. Silencing of the methionine sulfoxide reductase A gene results in loss of mitochondrial membrane potential and increased ROS production in human lens cells. Exp Eye Res. 83, 1281-6. 
Marchetti, M. A., Pizarro, G. O., Sagher, D., Deamicis, C., Brot, N., Hejtmancik, J. F., Weissbach, H., Kantorow, M., 2005. Methionine sulfoxide reductases B1, B2, and B3 are present in the human lens and confer oxidative stress resistance to lens cells. Invest Ophthalmol Vis Sci. 46, 2107-12.

Mary, J., Vougier, S., Picot, C. R., Perichon, M., Petropoulos, I., Friguet, B., 2004. Enzymatic reactions involved in the repair of oxidized proteins. Exp Gerontol. 39, 1117-23.

Moskovitz, J., 2005. Methionine sulfoxide reductases: ubiquitous enzymes involved in antioxidant defense, protein regulation, and prevention of aging-associated diseases. Biochim Biophys Acta. 1703, 213-9.

Moskovitz, J., Bar-Noy, S., Williams, W. M., Requena, J., Berlett, B. S., Stadtman, E. R., 2001. Methionine sulfoxide reductase (MsrA) is a regulator of antioxidant defense and lifespan in mammals. Proc Natl Acad Sci U S A. 98, 12920-5.

Moskovitz, J., Flescher, E., Berlett, B. S., Azare, J., Poston, J. M., Stadtman, E. R., 1998. Overexpression of peptide-methionine sulfoxide reductase in Saccharomyces cerevisiae and human $\mathrm{T}$ cells provides them with high resistance to oxidative stress. Proc Natl Acad Sci U S A. 95, 14071-5.

Moskovitz, J., Weissbach, H., Brot, N., 1996a. Cloning the expression of a mammalian gene involved in the reduction of methionine sulfoxide residues in proteins. Proc Natl Acad Sci U S A. 93, 2095-9.

Moskovitz, J., Jenkins, N. A., Gilbert, D. J., Copeland, N. G., Jursky, F., Weissbach, H., Brot, N., 1996b. Chromosomal localization of the mammalian peptide-methionine sulfoxide reductase gene and its differential expression in various tissues. Proc Natl Acad Sci U S A. 93, 3205-8.

Ogawa, F., Sander, C. S., Hansel, A., Oehrl, W., Kasperczyk, H., Elsner, P., Shimizu, K., Heinemann, S. H., Thiele, J. J., 2006. The repair enzyme peptide methionine-Ssulfoxide reductase is expressed in human epidermis and upregulated by UVA radiation. J Invest Dermatol. 126, 1128-34.

Petropoulos, I., Conconi, M., Wang, X., Hoenel, B., Bregegere, F., Milner, Y., Friguet, B., 2000. Increase of oxidatively modified protein is associated with a decrease of proteasome activity and content in aging epidermal cells. J Gerontol A Biol Sci Med Sci. 55, B220-7.

Petropoulos, I., Friguet, B., 2005. Protein maintenance in aging and replicative senescence: a role for the peptide methionine sulfoxide reductases. Biochim Biophys Acta. 1703, 261-6. 
Petropoulos, I., Friguet, B., 2006. Maintenance of proteins and aging: The role of oxidized protein repair. Free Radic Res. 40, 1269-76.

Petropoulos, I., Mary, J., Perichon, M., Friguet, B., 2001. Rat peptide methionine sulphoxide reductase: cloning of the cDNA, and down-regulation of gene expression and enzyme activity during aging. Biochem J. 355, 819-25.

Picot, C. R., Perichon, M., Cintrat, J. C., Friguet, B., Petropoulos, I., 2004. The peptide methionine sulfoxide reductases, MsrA and MsrB (hCBS-1), are downregulated during replicative senescence of human WI-38 fibroblasts. FEBS Lett. 558, 74-8.

Picot, C. R., Petropoulos, I., Perichon, M., Moreau, M., Nizard, C., Friguet, B., 2005. Overexpression of MsrA protects WI-38 SV40 human fibroblasts against $\mathrm{H}(2) \mathrm{O}(2)-$ mediated oxidative stress. Free Radic Biol Med. 39, 1332-1341.

Rattan, S. I., 2004. Aging intervention, prevention, and therapy through hormesis. J Gerontol A Biol Sci Med Sci. 59, 705-9.

Schallreuter, K. U., Rubsam, K., Chavan, B., Zothner, C., Gillbro, J. M., Spencer, J. D., Wood, J. M., 2006. Functioning methionine sulfoxide reductases A and B are present in human epidermal melanocytes in the cytosol and in the nucleus. Biochem Biophys Res Commun. 342, 145-52.

Scharffetter-Kochanek, K., Brenneisen, P., Wenk, J., Herrmann, G., Ma, W., Kuhr, L., Meewes, C., Wlaschek, M., 2000. Photoaging of the skin from phenotype to mechanisms. Exp Gerontol. 35, 307-16.

Vougier, S., Mary, J., Dautin, N., Vinh, J., Friguet, B., Ladant, D., 2004. Essential role of methionine residues in calmodulin binding to Bordetella pertussis adenylate cyclase, as probed by selective oxidation and repair by the peptide methionine sulfoxide reductases. J Biol Chem. 279, 30210-8.

Vougier, S., Mary, J., Friguet, B., 2003. Subcellular localization of methionine sulphoxide reductase A (MsrA): evidence for mitochondrial and cytosolic isoforms in rat liver cells. Biochem J. 373, 531-7.

Wlaschek, M., Tantcheva-Poor, I., Naderi, L., Ma, W., Schneider, L. A., Razi-Wolf, Z., Schuller, J.,Scharffetter-Kochanek, K., 2001. Solar UV irradiation and dermal photoaging. J Photochem Photobiol B. 63, 41-51.

Yermolaieva, O., Xu, R., Schinstock, C., Brot, N., Weissbach, H., Heinemann, S. H., Hoshi, T., 2004. Methionine sulfoxide reductase A protects neuronal cells against brief hypoxia/reoxygenation. Proc Natl Acad Sci U S A. 101, 1159-64. 
Figure 1

A

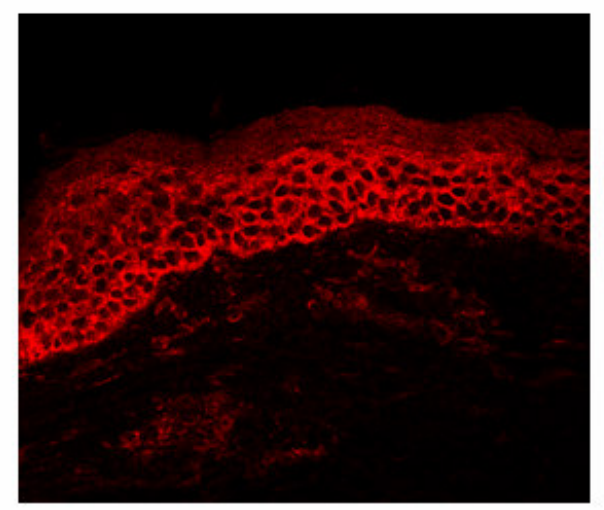

B

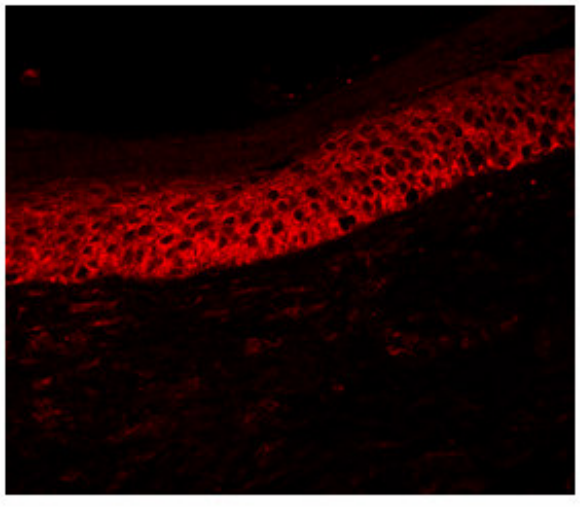

c

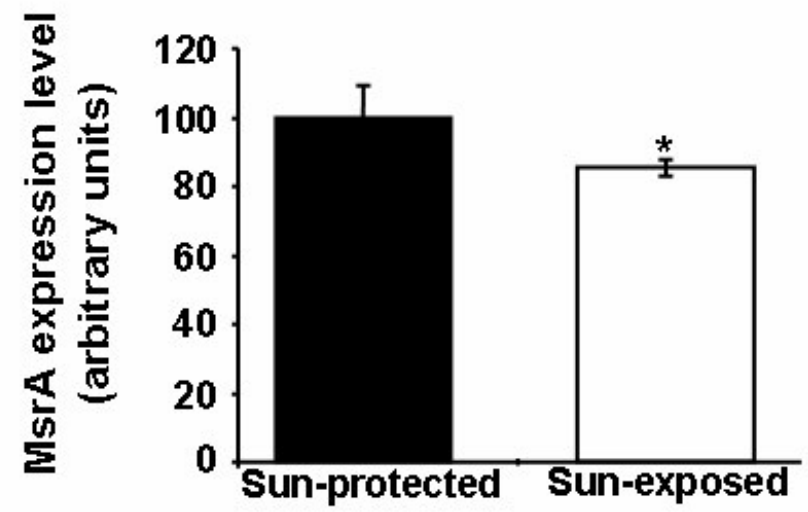


Figure 2

A

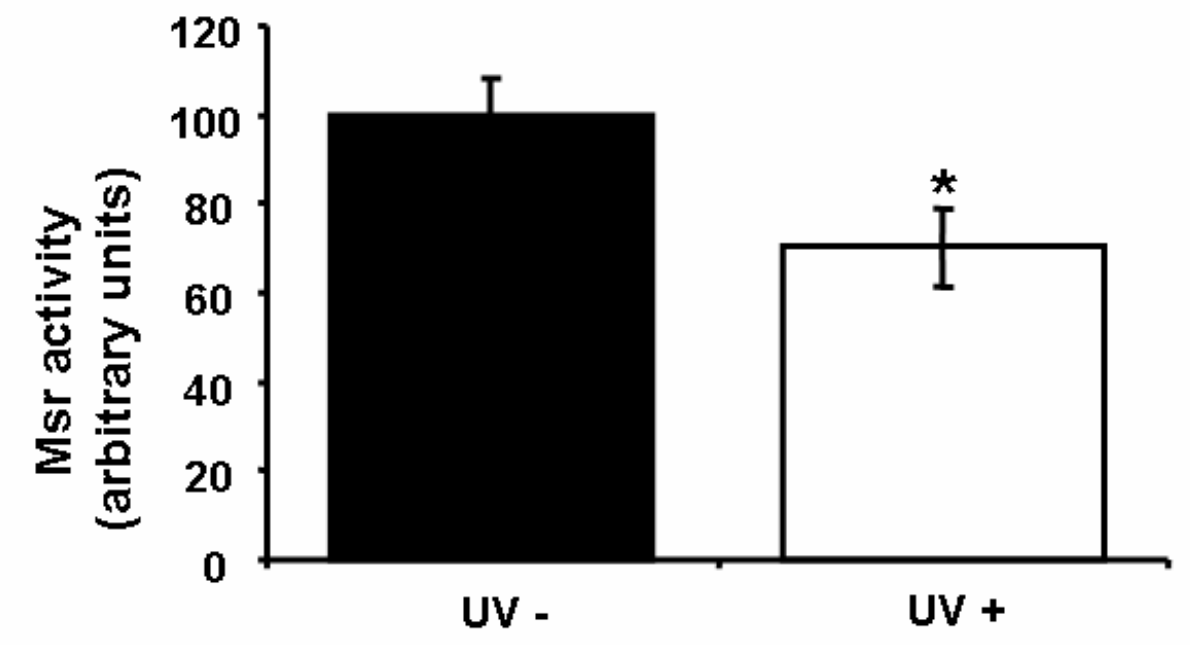

B

C UV-UV +

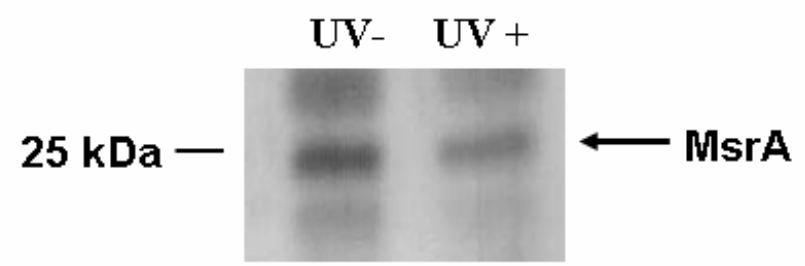

